\title{
Future libraries: dreams, madness \& reality
}

RECENSÕES

\author{
CRAWFORD, Walt, GORMAN, \\ Michael. Future libraries: \\ dreams, madness \& reality. \\ Chicago and London: \\ American Library Association, \\ 1995.
}

"Era o melhor dos tempos, era o pior dos tempos", dizia Dickens sobre a época da revolução francesa. Para muitos analistas do momento atual, esta afirmação pode ser também aplicada aos tempos atualmente vividos, principalmente quando se considera o impacto que as novas tecnologias de informação eletrônica estão tendo na sociedade, em especial naquelas instituições tradicionalmente dedicadas à conservação e disseminação de informação, ou seja, as bibliotecas.

Para muitos, é a aldeia global macluhiana que se torna concreta, um mundo que se faz pequeno, minúsculo mesmo, pela comunicação instantânea tornada possível por meios eletrônicos. E é surpreendente verificar como o ufanismo em torno dessas tecnologias parece dominar todas as visões, ao mesmo tempo em que se vê a facilidade com que perspectivas positivamente entusiasmadas às vezes se deixam levar pelo maraviIhamento. É fácil deixar-se cegar pelas supostas benesses de um mundo dominado pela informação eletrônica, pelo "melhor dos mundos", duvidando até mesmo da hipótese de que ele possa ter em seu interior sua própria negação, constituir o seu próprio reverso. É contra essa atitude de cegueira no que diz respeito às bibliotecas do futuro que se levantam as vozes de Walt Crawford e Michael Gorman, dois conceituados pesquisadores norte-americanos, em seu livro Future libraries: dreams, madness \& reality, publicado pela American Library Association.

O livro inicia quase que com uma declaração de amor às bibliotecas, destacando a crença dos autores nos "valores permanentes das bibliotecas e da biblioteconomia". Desde o início, destacam, assim, sua parcialidade, deixando cla- ro que não se alinham com os apocalípticos que defendem o desaparecimento de livros e bibliotecas como a conseqüência inevitável da disseminação da informação eletrônica. São sectários na defesa da instituição "biblioteca", bem como dos livros tradicionais enquanto instrumentos de armazenamento e comunicação da informação. Declaradamente. Abertamente. Despudoradamente sectários, como se estivessem desafiando os opositores a lançar-Ihes as pedras, tomates e ovos podres que costumam ser endereçados àqueles que se insurgem contra as idéias dominantes na sociedade.

É um livro escrito com paixão. Muita paixão. Não admira que, através da leitura, quase que sem notar, o leitor se veja concordando com os autores em muitos pontos. De fato, é fácil perceber que existe muita desinformação transformada em previsão infalível, muitos sonhos tresloucados expressos como as certezas mais absolutas do mundo. Que a realidade pode ser bastante diferente do que afirmam os entusiastas do mundo eletrônico. Que é preciso fazer a contraposição a essas idéias, diminuir a sede com que se vai ao pote, para evitar que este se quebre. É isto que Crawford e Gorman procuram fazer. Com bastante cuidado, eles vão alinhavando as previsões e desmontando-as uma por uma, com precisão quase cirúrgica.

O propalado fim da palavra impressa em suporte papel é um dos pontos que o livro mais se preocupa em desmascarar. Para os autores, "uma das previsões mais idiotas do futuro todo-eletrônico é a idéia de que todos irão ler a partir de dispositivos computadorizados. Tal coisa pode não ser impossível, mas ela é implausível por um número de razões. Os fatos são que os livros funcionam e 
funcionam melhor que qualquer alternativa para leitura prolongada. Enquanto os dispositivos computadorizados são melhores para a comunicação de dados e pequenos pacotes de informação, mesmo aquelas pessoas mais instruídas tecnologicamente, que não têm seus próprios machados para afiar e que ainda gastam tempo para ler confirmam o óbvio: para o texto linear ou mais que uns poucos parágrafos, a impressão em papel é o meio predileto (p. 17-8)".

Muitas pessoas, dizem Crawforde Gorman, estão dominadas pelo tecnolust, algo que as faz "olhar para as taxas de crescimento de uma nova tecnologia em seu primeiro ano e projetar essas taxas no futuro indefinido" (p. 36). São aquelas pessoas que não têm dificuldade em afirmar que a tecnologia para determinada realidade ainda não está disponível, mas que ela certamente o estará em alguns poucos meses ou anos. Assim vai ser, desta forma com certeza acontecerá, dizem. Os novos artefatos vão tomar o lugar dos antigos, gerando sua desaparição. Para eles e sobre eles, Crawford e Gorman lembram que "a maioria das inovações falham! Algumas vezes falham antes de chegar ao mercado; algumas vezes logo depois; e algumas vezes depois de aparentemente terem se estabelecido em mercados sólidos (p. 43)". E alinham então os casos de tecnologias fracassadas, como as várias tentativas de desenvolvimento do videodisco e muitas outras que prometiam maravilhas e acabaram desaparecendo prematuramente.

As possibilidades de publicação e distribuição da informação por via eletrônica constituem talvez o capítulo mais interessante do livro, à medida que os autores conseguem deixar um pouco de lado a sua verve destrutiva e elaborar análises bastante ponderadas do que permanecerá em formato tradicional impresso e do que deverá passar para os formatos eletrônicos. Alinham e analisam os vários projetos atualmente existentes que visam à transferência de textos impressos para o suporte eletrônico, entre eles os projetos Gutemberg e Xanadu. E manifestam sua descrença quanto à viabilidade econômica de ambas as iniciativas.
Outro conceito que parece irritar bastante os autores de Future libraries é o de desintermediação, a idéia de que "cada usuário deveria se tornar seu próprio bibliotecário de referência" (p. 107). Chegam a denominar a defesa dessa idéia de uma "tendência suicida", reprovando fortemente os bibliotecários que a defendem, quase chegando mesmo a chamá-los de traidores da profissão (não chegam a fazê-lo, propriamente, mas ficam bastante perto disso). Nada indica, defendem os autores, que a realidade se encaminhará para esse cenário: afinal, dizem, "mesmo aceitando que a maioria dos adultos poderia aprender a consertar seus próprios carros, encanamento, e trabalho elétrico - uma suposição que leva a um mundo até mesmo mais perigoso do que o de hoje por que diabos o fariam?" (p.108).

O livro de Crawford e Gorman constitui, em resumo, um grito de revolta contra 0 excesso de otimismo em relação ao mundo maravilhoso que a informação eletrônica, dizem por aí, poderá propiciar. Nem tudo está já totalmente delineado como tão facilmente se afirma, o futuro não é uma estrada prévia e irreversivelmente definida. É o que buscam a todo momento afirmar e reafirmar em seu livro, em uma repetição que às vezes chega a ficar monótona e acaba fazendo com que seus argumentos percam um pouco de sua força original. Usam uma linguagem forte para isso, talvez tentando marcar, pela rudeza de suas expressões, uma fundamental diferença entre sua posição intelectual e a daqueles que eles entendem como demasiadamente entusiasmados pelo novo mundo da informação eletrônica. $E$ ao usar essa linguagem forte, caem no mesmo tipo de excesso daqueles que denunciam. Perdem um pouco de sua objetividade e se fazem por demais intransigentes em sua negação do futuro que a informação eletrônica possibilitará atingir.
Não chegam, com isso, a invalidar suas teses, é claro. A exatidão de suas análises, em muitos aspectos, é maior do que sua exaltação ou que os termos utilizados. Os argumentos são sólidos, embora soem como enfurecidos (e o sejam realmente). Era, sem dúvida, necessário que alertas como os de Crawford e Gorman fossem feitos, apresentando uma contraposição a uma imagem de futuro que parece por demais axiomática. No entanto, a exaltação dos dois autores acaba fazendo com que o tiro saia um pouco pela culatra, à medida que pode levar os leitores a perceber o exagero da denúncia, fazendo brotar algumas dúvidas quanto à precisão das idéias que receberam. Se nem tudo é cor-de-rosa no futuro dominado pela informação eletrônica, talvez também não seja assim tão sombrio como o querem fazer acreditar os autores de Future Libraries. Mas é um livro que faz pensar e talvez esteja aí o seu maior mérito, muito mais do que oferecer um pessimismo incrédulo como contraposição ao otimismo ingênuo daqueles que busca denunciar. A verdade, afinal de contas, não tem donos. Pelo menos, não definitivos.

\section{Waldomiro Vergueiro}

Professor doutor do Departamento de Biblioteconomia e Documentação. Escola de Comunicações e Artes da Universidade de São Paulo. 